\title{
UJI BERBAGAI DOSIS DAN FREKUENSI PEMUPUKAN NPK PADA TANAH BERGAMBUT UNTUK MENINGKATKAN PRODUKSI BAWANG MERAH (Allium ascalonicum L.)
}

\author{
Test Various Doses and Frequency of NPK Fertilization in Peat Soil to Increase Shallot \\ Production (Allium ascalonicum L.)
}

\author{
Selvia Sutriana \\ Dosen Program studi Agroteknologi Fakultas Pertanian Universitas Islam Riau \\ Jl. Kaharuddin Nasution 113 Pekanbaru 28284 Riau \\ Email : selviasutriana@agr.uir.ac.id \\ [Diterima: April 2018; Disetujui: Agustus 2018]
}

\begin{abstract}
Lack of community interest in cultivating shallot because of the level of soil fertility in peatlands. The use of NPK 16:16:16 according to proper dosage and frequency of fertilization is important in increasing production. The purpose of this study was to determine the effect of various doses and frequency of NPK fertilization on peat soils to increase onion production. The research was carried out in the Faculty of Agriculture UIR experimental garden for 3 months, starting from September to November 2017. The design used was completely factorial 4 x 4, various dose factors were $100,200,300,400 \mathrm{~kg} / \mathrm{ha}$, and the frequency of fertilization factors were $1,2,3$ times. Observations were made on the production parameters namely the number of tubers, tuber diameter, wet weight, dry weight, and the percentage of tuber shrinkage. Observation data were analyzed statistically and presented in tabular form. The results showed that the effect of real interactions on the dry weight of tubers per clump, the best treatment dose was $100-400 \mathrm{~kg} / \mathrm{ha}$ with the fertilizing frequency of 1-3 times. The main effect of NPK fertilizer dose affects tuber diameter, the best treatment dosage is $300-400 \mathrm{~kg} / \mathrm{ha}$, while fertilizing frequency significantly influences tuber diameter, the best treatment is 3 times fertilization, while on dry tuber weight per clump, the best treatment is 1 and 3 times fertilization.
\end{abstract}

Keywords: Shallot, Dose, Frequency, NPK, Production

\begin{abstract}
ABSTRAK
Kurangnya minat masyarakat dalam membudidayakan bawang merah karena tingkat kesuburan tanah di lahan gambut. Penggunaan pupuk NPK 16:16:16 sesuai dosis dan frekuensi pemupukan yang tepat penting dalam meningkatkan produksi. Tujuan penelitian adalah mengetahui pengaruh berbagai dosis dan frekuensi pemupukan NPK pada tanah bergambut untuk meningkatkan produksi bawang merah. Penelitian dilaksanakan di Kebun percobaan Fakultas Pertanian UIR selama 3 bulan, dimulai bulan September sampai November 2017. Rancangan yang digunakan Acak Lengkap Faktorial 4 x 4, faktor Berbagai dosis yaitu 100, 200, 300, $400 \mathrm{~kg} / \mathrm{ha}$ dan faktor Frekuensi pemupukan yaitu 1, 2, 3 kali. Pengamatan dilakukan pada parameter produksi yaitu jumlah umbi, diameter umbi, berat basah, berat kering dan persentase susut umbi. Data pengamatan dianalisis secara statistik dan disajikan dalam bentuk tabel. Hasil penelitian menunjukkan bahwa pengaruh interaksi nyata pada berat kering umbi per rumpun, perlakuan terbaik dosis $100-400 \mathrm{~kg} / \mathrm{ha}$ dengan frekuensi pemupukan $1-3$ kali. Pengaruh utama dosis pupuk NPK berpengaruh terhadap diameter umbi, perlakuan terbaik dosis $300-400 \mathrm{~kg} / \mathrm{ha}$, sedangkan frekuensi pemupukan berpengaruh nyata terhadap diameter umbi, perlakuan terbaik 3 kali pemupukan sedangkan berat umbi kering per rumpun, perlakuan terbaik 1 dan 3 kali pemupukan.
\end{abstract}

Kata kunci: Bawang merah, Dosis, Frekuensi, NPK, Produksi 


\section{PENDAHULUAN}

Bawang merah tidak hanya dikenal untuk bumbu penyedap makanan saja, tetapi juga sebagai obat herbal. Hasil penelitian Ismawati dan Hamidy (2012), menyatakan bahwa kandungan quersetin dan allisin pada bawang merah berperan menurunkan kolesterol darah dan sebagai antioksidan. Selanjutnya 100 g bawang merah mengandung: kalori 39, protein $150 \mathrm{mg}$, lemak 0,3 , karbohidrat $9,2 \mathrm{~g}$, vitamin A 50, vitamin B $0,3 \mathrm{mg}$, vitamin C 200 $\mathrm{mg}$, kalsium $36 \mathrm{mg}$, fosfor $40 \mathrm{mg}$ dan air $20 \mathrm{~g}$ (Departeman Pertanian dalam Napitupulu, D dan L. Winarto,2010).

Berdasarkan Data Badan Pusat Statistik (2017) menyatakan bahwa luas panen, produksi dan produktivitas bawang merah di Indonesia tahun 2015 dan 2016 mengalami kenaikkan dan penurunan pada beberapa Provinsi. Untuk luas panen nasional meningkat $21,54 \%$, di provinsi Riau peningkatan 82,93\% (tahun 201541 ha dan tahun 2016 menjadi 75 ha). Produksi nasional meningkat $1.066,47 \%$, untuk provinsi Riau 2063,45\% (tahun 2015140 ton dan 2016 3.031 ton). Produktivitas nasional mengalami penurunan 3,98\%, untuk provinsi Riau terjadi peningkatan $18,26 \%$ (2015 3,42 ton/ha dan 2016 4,04 ton/ha). Budidaya bawang merah di Riau tergolong pemula karena data yang tercatat di Badan Pusat Statistik pertama kali pada tahun 2013, produktivitas yang dihasilkan juga rendah jika dibandingkan dengan provinsi Sumatra Utara dan Sumatra Barat.

Rendahnya produktivitas bawang merah di Riau, selain karena tingkat kesuburan tanah gambut, dimana kelebihan air hal ini berdampak pada kurangnya oksigen $\left(\mathrm{O}_{2}\right)$ sehingga menghambat pertumbuhan akar, juga karena pemupukan yang belum dilakukan secara intensif dan sesuai anjuran.

Lahan gambut Riau terluas di Pulau Sumatera yaitu $\pm 4,04$ juta $\mathrm{Ha}$ atau $64 \%$ dari luas total lahan gambut di Sumatera, tetapi hanya 19\% lahan gambut yang baik untuk pertanian (BB Litbang SDLP, 2008). Pengembangan tanaman hortikultura khususnya bawang merah pada lahan gambut masih belum dimanfaatkan sebaik mungkin, padahal ini merupakan suatu peluang bagi masyarakat untuk membudidayakan tanaman bawang merah guna memenuhi kebutuhan dan menambah pendapatan keluarga. Salah satu varietas bawang merah yang di kembangkan di Riau adalah Bima brebes.

Untuk meningkatkan hasil bawang merah, hal-hal yang perlu dipenuhi, antara lain: 1. lingkungan yang ketersediaan tanah, cahaya, air, dan unsurhara tercukupi, 2. memberikan dosis pupuk tepat dan seimbang serta frekuensi pemupukan yang sesuai dengan kebutuhan tanaman.

Pupuk NPK salah satu sumber hara untuk proses pertumbuhan dan produksi bawang merah, dimana mengandung 3 unsurhara makro (Nitrogen 16\%, Phospat 16\%, Kalium 16\%), dan bersifat netral, hidroskopis atau mudah larut sehingga cepat diserap tanaman. Menurut Jumin (2012), fungsi Nitrogen: mempercepat pertumbuhan vegetatif, kandungan protein, kemampuan tanaman untuk menyerap unsurhara lain dan pengisian pada tanaman biji bijian berjalan baik. Fungsi Fosfat: memperbaiki perkembangan akar, pembungaan, pembuahan, mempercepat pemasakan buah, mengurangi kerontokan buah dan tahan terhadap terhadap penyakit. Fungsi Kalium: mengatur keseimbangan pupuk nitrogen dan fosfat, pembentukan karbohidrat, klorofil, umbi, perkaran baik dan lebih tahan terhadap penyakit. Frekuensi pemupukan juga menjadi faktor penting untuk menjamin ketersediaan unsurhara bagi tanaman didalam tanah.

\section{BAHAN DAN METODE}

Pelaksanaan penelitian di Lahan Fakultas Pertanian Universitas Islam Riau Pekanbaru, selama 3 bulan terhitung dari September - November 2017.

Bahan-bahan penelitian adalah bibit varietas brebes, pupuk NPK 16:16:16, pupuk kompos serasah jagung, dolomite, Dithane M45. Alat-alat yang digunakan: cangkul, garu, handsprayer, timbangan analitik, meteran, gembor, $\mathrm{pH}$ meter.

Penelitian menggunakan Rancangan Acak Lengkap (RAL), terdiri dari 2 faktor yaitu: Faktor berbagai dosis pupuk NPK, dengan 4 taraf: 100, 200, 300, $400 \mathrm{~kg} / \mathrm{ha}$ dan faktor Frekuensi pemupukan NPK dengan 3 taraf: 1, 2, 3 kali, dan ulangan 3 kali, sehingga diperoleh 36 satuan percobaan, dimana tiap plot terdapat 25 tanaman dengan sampel 10 tanaman. Jumlah keseluruhan 900 tanaman. 
Hasil pengamatan perlakuan dianalisa secara statistik dan uji lanjut BNJ taraf $5 \%$.

Pelaksanaan penelitian meliputi pengolahan lahan dengan ukuran plot $1 \mathrm{mx} 1 \mathrm{~m}$ sebanyak 36 plot, jarak antar plot $50 \mathrm{~cm}$, lalu tanah digemburkan dengan kedalaman $20 \mathrm{~cm}$. Dolomit diberikan 2 minggu sebelum tanam dengan dosis 3 ton/ha, tujuannya untuk menetralkan $\mathrm{pH}$ tanah dan Pupuk kompos serasah jagung dengan dosis 15 ton/ha diberikan seminggu sebelum tanam. 2 jam sebelum penanaman umbi bagian ujung dipotong $1 / 3$, kemudian diberikan fungisida dithane M $452 \mathrm{~g}$, dicampurkan pada bibit bawang merah yang sudah dipotong, tujuannya untuk mencegah serangan penyakit pada bawang merah. Pemberian perlakuan disesuaikan dengan dosis yang telah ditentukan yaitu 100, 200, 300 dan $400 \mathrm{~kg} / \mathrm{ha}$ dan frekuensi 1 kali (saat tanam), 2 kali (saat tanam dan $3 \mathrm{mst}$ ), 3 kali (saat tanam, 3 mst dan $6 \mathrm{mst}$ ). Pemeliharaan merupakan faktor penting dalam budidaya tanaman bawang merah yaitu penyiraman, penyiangan, pengendalian hama dan penyakit serta panen dilakukan pada umur 65 hst. Parameter yang diamati adalah jumlah umbi per rumpun, diameter umbi, berat umbi basah per plot, berat umbi kering per plot dan persentase susut umbi.

\section{HASIL DAN PEMBAHASAN}

\section{Jumlah umbi per rumpun}

Data pada Tabel 1.a menunjukkan bahwa hasil pengamatan terhadap parameter pengamatan jumlah umbi per rumpun setelah dianalisis ragam tidak berpengaruh nyata baik interaksi dan utama. Hal ini diduga lebih dipengaruhi oleh faktor genetik dibanding faktor pemupukan. Sama dengan peneliti Azmi, dkk (2011) yang menyatakan bahwa faktor genetik lebih dominan mempengaruhi Produktivitas umbi bawang dan sedikit dipengaruhi oleh lingkungan.

Pada tanaman bawang merah, anakan atau umbi berfungsi dalam penyimpanan cadangan makanan. Semakin banyak jumlah daun, maka akan meningkatkan jumlah pelepah daun, sehingga umbi yang dihasilkan besar pula. Hakikatnya umbi lapis bawang merah merupakan modifikasi dari pelepah daun yang tersusun rapi.

\section{Diameter umbi}

Data pada Tabel 1.b. menunjukkan bahwa hasil pengamatan diameter umbi setelah dianalisis ragam pengaruh interaksi tidak nyata tetapi pengaruh utama nyata.

Pupuk NPK terbaik pada dosis $300-$ $400 \mathrm{~kg} / \mathrm{ha}$ dengan rerata $2,79 \mathrm{~cm}$ dan $2,82 \mathrm{~cm}$, berbeda nyata dengan dosis $100 \mathrm{~kg} / \mathrm{ha}$ dan 200 $\mathrm{kg} / \mathrm{ha}$. Hal ini dikarenakan umbi bawang merah mampu menghasilkan diameter terbesar pada dosis $300 \mathrm{~kg}-400 \mathrm{~kg} / \mathrm{ha}$. Sedangkan frekuensi pemupukan terbaik adalah 3 kali yaitu $3,05 \mathrm{~cm}$ dan berbeda nyata dengan frekuensi 1 dan 2 kali. Ini berarti frekuensi pemupukan 3 kali pada pada saat tanam, 3 dan 6 mst mempengaruhi terhadap pembesaran umbi bawang merah karena diberikan secara bertahap sesuai kebutuhan untuk tinggi tanaman, pembentukan umbi dan pembesaran umbi.

\section{Berat basah umbi per rumpun}

Data pada Tabel 1.c. menunjukkan bahwa hasil pengamatan berat basah umbi per rumpun setelah dianalisis ragam tidak berpengaruh nyata

Rata-rata berat umbi basah yang dihasilkan 36,10 g/rumpun atau 9 ton/ha. Artinya tanaman bawang merah bisa menghasilkan berat umbi basah sesuai deskripsi walaupun dibudidayakan pada lahan gambut. Sama dengan penelitian Sinaga et al. (2013) yang diperoleh bahwa varietas dapat beradaptasi dengan baik dilingkungan tumbuh karena varietas terdiri dari satu macam genotif, dan mempunyai susunan genetik untuk mengendalikan sifat fisiologi dan morfologi. 
Tabel 1: Rerata Produksi bawang merah pada perlakuan dosis dan frekuensi pemupukan NPK 16:16:16

\begin{tabular}{|c|c|c|c|c|}
\hline \multirow{2}{*}{$\begin{array}{c}\text { Dosis NPK } \\
(\mathrm{kg} / \mathrm{ha})\end{array}$} & \multicolumn{3}{|c|}{ Frekuensi Pemupukan NPK 16:16:16 (kali) } & \multirow[t]{2}{*}{ Rerata } \\
\hline & 1 & 2 & 3 & \\
\hline \multicolumn{5}{|c|}{ a. Jumlah umbi per rumpun } \\
\hline 100 & 8,07 & 7,63 & 7,60 & 7,77 \\
\hline 200 & 8,35 & 8,87 & 6,57 & 6,47 \\
\hline 300 & 7,50 & 9,13 & 8,50 & 8,37 \\
\hline 400 & 7,60 & 6,75 & 9,00 & 7,78 \\
\hline Rerata & 7,88 & 8,09 & 7,95 & 7,97 \\
\hline \multicolumn{5}{|c|}{$\mathrm{KK}=17,98 \%$} \\
\hline \multicolumn{5}{|c|}{ b. Diameter umbi $(\mathrm{cm})$} \\
\hline 100 & 2,56 & 2,14 & 2,90 & $2,53 \mathrm{~b}$ \\
\hline 200 & 2,67 & 2,16 & 3,02 & $2,62 \mathrm{~b}$ \\
\hline 300 & 2,77 & 2,48 & 3,14 & $2,79 \mathrm{a}$ \\
\hline 400 & 2,81 & 2,49 & 3,16 & $2,82 \mathrm{a}$ \\
\hline Rerata & $2,70 \mathrm{~b}$ & $2,32 \mathrm{c}$ & $3,05 \mathrm{a}$ & \\
\hline \multicolumn{5}{|l|}{$\mathrm{KK}=2,67 \%$} \\
\hline \multicolumn{5}{|c|}{ c. Bobot basah umbi per rumpun (g) } \\
\hline 100 & 38,42 & 38,14 & 43,57 & 40,04 \\
\hline 200 & 32,97 & 31,76 & 30,31 & 31,68 \\
\hline 300 & 33,19 & 42,09 & 33,75 & 36,34 \\
\hline 400 & 48,04 & 31,73 & 29,28 & 36,35 \\
\hline Rerata & 38,15 & 35,93 & 34,23 & 36,10 \\
\hline \multicolumn{5}{|l|}{$\mathrm{KK}=11,36 \%$} \\
\hline \multicolumn{5}{|c|}{ d. Bobot kering umbi per rumpun $(\mathrm{g})$} \\
\hline 100 & $32,47 \mathrm{ab}$ & $27,62 \mathrm{ab}$ & $35,74 \mathrm{ab}$ & 31,94 \\
\hline 200 & $26,92 \mathrm{~b}$ & $28,29 \mathrm{ab}$ & $27,60 \mathrm{ab}$ & 27,60 \\
\hline 300 & $29,14 \mathrm{ab}$ & $25,99 \mathrm{~b}$ & $28,48 \mathrm{ab}$ & 27,87 \\
\hline 400 & $38,80 \mathrm{a}$ & $24,78 \mathrm{~b}$ & $23,35 \mathrm{~b}$ & 28,98 \\
\hline Rerata & $31,83 \mathrm{a}$ & $26,67 \mathrm{~b}$ & $28,79 \mathrm{ab}$ & 29,09 \\
\hline \multicolumn{5}{|l|}{$\mathrm{KK}=10,61 \%$} \\
\hline \multicolumn{5}{|c|}{$\begin{array}{ll}\text { e. } & \text { Persentase susut umbi (\%) }\end{array}$} \\
\hline 100 & 16,44 & 17,78 & 32,03 & 22,08 \\
\hline 200 & 25,09 & 23,70 & 18,79 & 22,53 \\
\hline 300 & 7,54 & 29,05 & 24,66 & 20,42 \\
\hline 400 & 15,07 & 21,93 & 20,60 & 19,20 \\
\hline Rerata & 16,03 & 23,11 & 24,02 & 21,06 \\
\hline $\mathrm{KK}=24,21 \%$ & & & & \\
\hline
\end{tabular}

\section{Berat kering umbi per rumpun}

Data pada Tabel 1.d. menunjukkan bahwa hasil pengamatan berat kering umbi per rumpun setelah dianalisis ragam secara interaksi berpengaruh nyata dan secara utama dosis pupuk tidak berpengaruh tetapi frekuensi pemupukan berpengaruh nyata.

Pengaruh interaksi dosis pupuk 100 sampai $400 \mathrm{~kg} / \mathrm{ha}$ mendapatkan hasil terbaik yang dikombinasikankan dengan 1, 2 dan 3 kali pemupukan. Berat kering tertinggi dihasilkan $38,80 \mathrm{~g}$ atau 9,7 ton/ha dan rata-rata berat umbi kering yang dihasilkan 29,09 g/rumpun atau 7,27 ton/ha. Hasil yang diperoleh masih rendah dbandingkan deskripsi bawang merah varietas bima brebes, hal ini dikarenakan faktor kesuburan tanah gambut dan lingkungan serta pupuk yang diberikan belum memenuhi unsurhara yang dibutuhkan tanaman. Sartono (2010) menyatakan pertumbuhan dan produksi bawang merah tidak hanya dipengaruhi faktor eksternal tetapi faktor internal.

Hasil penelitian Abdulrachman dan Susanti (2004) mengatakan bahwa 
pertumbuhan dapat lebih optimal dengan pemberian pupuk $\mathrm{K}$ yang cukup kedalam tanah sesuai dengan kebutuhan tanaman tersebut. Dapat dilihat dengan pemberian pupuk NPK dosis $400 \mathrm{~kg} / \mathrm{ha}$ menunjukkan hasil yang lebih baik dibandingkan dosis lainnya. Ini sangat membantu untuk proses fotosintesis dalam pembentukan senyawa organik baru yang dibawa ke organ tempat pembesaran umbi. Sedangkan pendapat Bybordi dan Malakouti (2003) menyatakan bahwa kandungan $\mathrm{K}$ yang ada dalam pupuk NPK akan menghasilkan umbi yang berkualitas, dan menurut Russell dalam Napitupulu dan Winarto (2010) menyatakan pupuk sebagai sumber nutrisi relevan untuk pertumbuhan tanaman. Penambahan pupuk $\mathrm{K}$ memberikan pengaruh sangat nyata terhadap bobot umbi kering per rumpun.

Menurut Sudrajat, dkk (2010), bahwa berat kering umbi memperlihatkan jumlah bahan kering yang diakumulasikan selama pertumbuhan, hampir $90 \%$ bahan kering tanaman adalah hasil fotosintesis. Analisis pertumbuhan yang dinyatakan dengan bobot umbi kering yaitu kemampuan tanaman melakukan proses fotosintesa. Berat kering tanaman akan menggambarkan tentang efisiensi proses fisiologi tanaman dan merupakan indikator untuk mengetahui kualitas benih atau bibit yang digunakan.

\section{Persentase Susut Umbi}

Data pada Tabel 1.e. menunjukkan bahwa hasil pengamatan persentase susut umbi setelah dianalisis ragam secara interaksi dan utama tidak berpengaruh nyata.

Jika dilihat dari angka persentase susut umbi lebih besar dibandingkan deksripsi bawang merah yaitu rata-rata $29 \%$, sedangkan deskripsi $22 \%$. Hal ini dikarenakan kualitas umbi yang dihasilkan kurang baik, sesuai dengan pendapat Mutia, A.K, dkk (2014), yang menyatakan bahwa susut bobot umbi selama proses penyimpanan untuk mengetahui dan menguji tingkat kesegaran. Semakin tinggi susut umbi maka semakin kurang tingkat kesegarannya, sebaliknya rendah susut bobot umbi menunjukkan kualitas umbi baik dan masa simpan lebih lama.

$$
\text { Pendapat Soedomo (2006), }
$$

menyatakan bahwa selama proses penyimpanan lebih kurang 5 - 30\% terjadi susut umbi. Bawang merah dengan susut umbi rendah memiliki daya simpan baik, tidak mudah busuk serta dapat digunakan untuk penanaman berikutnya. Bawang merah memiliki masa simpan lebih panjang ( $2-3$ bulan) karena memiliki kandungan air dalam umbi yang ideal, kekerasan tekstur serta jumlah padatan terlarut.

\section{KESIMPULAN}

Dari hasil penelitian dapat disimpulkan bahwa:

1. Secara interaksi berpengaruh nyata pada berat umbi kering per rumpun, perlakuan terbaik $100-400 \mathrm{~kg} / \mathrm{ha}$ dengan 1 - 3 kali pemupukan

2. Secara utama dosis pupuk NPK berpengaruh nyata pada diameter umbi, perlakuan terbaik dosis $300-400$ $\mathrm{kg} / \mathrm{ha}$.

3. Secara utama frekuensi pemupukan berpengaruh nyata pada umur diameter umbi, perlakuan terbaik 3 kali pemupukan dan berat umbi kering per rumpun, perlakuan terbaik 1 dan 3 kali pemupukan.

4. Tidak berpengaruh nyata pada parameter jumlah umbi, berat umbi basah dan persentase susut umbi karena faktor genetik tanaman bawang merah lebih dominan mempengaruhi produktivitas dibandingkan perlakuan pemupukan.

\section{UCAPAN TERIMA KASIH}

Ucapan terimakasih disampaikan kepada Ketua LPPM Universitas Islam Riau yang telah mendanai penelitian ini, 
Rektor Universitas Islam Riau, Dekan Fakultas Pertanian dan rekan-rekan dosen serta mahasiswa yang telah membantu dalam penelitian serta penulisan jurnal ini.

\section{DAFTAR PUSTAKA}

Abdulrachman, S. dan Z. Susanti. 2004. Pengaruh Pemberian Zeolit terhadap Peningkatan Efisiensi Pupuk P dan K pada Tanaman Padi. J. Zeolit Indonesia. 3:1-12.

Azmi, C., I. M. Hidayat, dan G. Wiguna. 2011. Pengaruh Varietas dan Ukuran Umbi terhadap Produktivitas Bawang Merah. Balai Penelitian Tanaman Sayuran. J. Hort. 21(3):206-213

Badan Pusat Statistika. 2017. Luas Panen, Produksi, Produktivitas Bawang Merah Tahun 2016.

BB Litbang SDLP (Balai Besar Penelitian dan Pengembangan Sumberdaya Lahan Pertanian. 2008. Laporan tahunan 2008, Konsorsium penelitian dan pengembangan perubahan iklim pada sektor pertanian. Balai Pesar Penelitian dan Pengembangan Sumberdaya Lahan Pertanian, Bogor.

Bybordi, A. and M.J. Malakouti, 2003. The Effect of Various Rates of Potassium, Zinc, and Copper on the Yield and Quality of Onion Under Saline Conditions In Two Major Onion Growing Regions of East Azarbayjan. Agric. Sci. and Technol. 17:43-52.
Ismawati, E Asni dan M.Y. Hamidy. 2012. Pengaruh Air Perasan Umbi Bawang Merah (Allium ascalonicum L.) terhadap Malondialdehid (MDA) Plasma Mencit yang diinduksi Hiperkolesterolemia. Jurnal Natur Indonesia, 14(2): 150-154

Jumin, HB. 2012. Dasar-dasar Agronomi. Bumi Aksara. Jakarta

Mutia, AK. 2014. Perubahan kualitas bawang merah (Allium ascalonicum L) selama penyimpanan pada tingkat kadar air dan suhu yang berbeda. Jurnal Pasca Panen 11 (2):108 - 115

Napitupulu, D dan L. Winarto. 2010. Pengaruh pemberian pupuk $\mathrm{N}$ dan $\mathrm{K}$ terhadap pertumbuhan dan produksi bawang merah. Jurnal Hortikultura 20 (1): $27-35$.

Sartono, P 2010, 'Perbaikan varietas bawang merah (Allium ascallonicum L.) melalui persilangan. AGRITECH. 12: 1-10

Sinaga, E.M, Bayu, E.S, Nuriadi, I. 2013. Adaptasi beberapa varietas bawang merah (Allium ascolenicum L) di dataran rendah medan. Jurnal Online Agroteknologi. Fakultas Pertanian Universitas Sumatra Utara. 1 (3)

Soedomo, R.P. 2006. Pengaruh jenis kemasan dan daya simpan umbi bibit bawang merah terhadap pertumbuhan dan hasil di lapangan. Jurnal Hortikultura 16 (3): 188-196 